Vol. 3, No. 1, 2016

UDC 330.341.1

N. S. Stanasyuk

Ph.D. in Economics, Associate Professor

Lviv Polytechnic National University

\title{
STRUCTURAL DEVELOPMENT OF INDUSTRIAL POTENTIAL OF UKRAINE
}

\begin{abstract}
The methodical aspects of analyzing of structural changes impact on the development of basic components of industrial potential of Ukraine are disclosed in this article. In the context of the offered methodology, the results of calculation of structural changes impact on the efficiency of fixed assets, labour potential, innovative and investment development of the industrial potential are shown in the fields of employment, capital investments, innovations and production of industrial goods. Conclusions as to the received analytical results are made determining the content of structural transformations of the industrial potential of Ukraine
\end{abstract}

Key words: structural changes, structural transformation and industrial potential.

\section{Formulation of the problem}

Emergence of structural crisis in the national economy stimulates to maintain effective government regulation of structural changes that appeared in a certain sector of the economy. Ukraine's decision to take on the modernization of industry makes it find out objective ways aimed at effective structural transformation of the industrial potential. The reason of this process is structural changes that took place in the world caused by the evolutional growth of the economy and the necessity of the industrial potential development as cause-and-effect process determined by the impact of the objective factors (innovations, investments, labour potential, capital etc.).

Factor analysis is a classical methodological instrument of determining the influence of certain factors on the of industrial potential development that allows to set cause-and-effect relations between structural changes and effective indicators of the industrial potential development. Though, primary indicators without tendentiousness of their changes are often used at calculations. This, in its turn, gives partial meaning of the received results and does not assist to provide complex evaluation of the existing situation. Analysis of interrelation between the structural changes of certain factors and certain indicators of the efficiency does not provide understanding of structural changes tendentiousness and reduces efficiency of the state regulation of structural transformation of the industrial potential.

\section{Analysis of recent researches and publications}

Taking into account the importance of the mentioned theme, the theory of structural transformations throughout the evolutional development of the economy is widely disclosed by foreign as well as native scientists. Among foreign researchers it is worth to mention J. Keynes [1], the founder of the new system of views on the development of the economy. The innovation of Keynes' theory implies the introduction of macroeconomic analysis into scientific environment and setting up of macroeconomic dependences between factors and processes as well as formation of the effective economic policy of state regulation of the market economy on this basis with the purpose to remove the discovered drawbacks. His the most famous follower was R. Harrod [2] who is considered to be the founder of the theory of economic growth. His model of economy contains factors which determine potential possibilities of national income growth in a long-run perspective. E. Domar [3] shared the same views, he considered investments to be a strategic factor of the economy growth.

Transition from administrative-command economy to the market one in the $90^{\text {th }}$ years of the last century caused the development of the native theory of structural transformations, and choice of changes towards Euro integration became a new incentive for modern researchers. A. Galchynskyi points out that Ukraine today is not yet ready to conduct postindustrial transformations [4]. Such conclusion is reasonable and determined by the considerable economic underdevelopment of the state in comparison with the leading European countries. Therefore, it's extremely important now 


\section{N. S. Stanasyuk}

to form powerful industrial potential within the context of innovative-investment development of the national economy.

A lot of native and foreign researchers connect structural changes with separation of certain cycles of economic development. Y. M. Chaika offers to distinguish small (4-6 years), medium (7-11 years) and long-run cycles (40-60 years) [5]. To our mind, it makes sense to separate six basic stages of structural economy development cycle offered by I. I. Pasinovych: structural crisis, structural changes, structural shifts, structural reforms, structural adjustment and structural transformation [6]. These stages are characteristic for structural development of the industrial potential as well, that, on one hand, is the result caused by internal structural crisis, and on the other hand, is the result from structural shifts in the economy of the country in whole.

At the same time, represented scientific achievements of native and foreign researchers as to the development of the theory of structural transformations do not solve the problem of structural development of the industrial potential as an inseparable part of national economy taking into account peculiarities of structural changes in the mentioned sector, that requires working out of appropriate methodical tools, due to their application it would be possible to get complex analytical picture of their influence.

\section{The objective of the article}

The objective of the article is to work out methodological bases of the analysis of structural shifts impact on the industrial potential development with the aim to assess tendentiousness of changes.

\section{research}

The presentation of the material of the

Structure of the industrial potential is a dynamic value that constantly changes under the influence of objective factors, thus modifying and adapting itself to certain economic conditions. Structural development is a logical reaction on structural changes, that in the long run will result in creating of more improved and adequate to modern economic realities structure of the industrial potential. Development of the national industrial potential takes place under the influence of structural changes of its basic components, that is social and labour, industrial and economic, finance and investment and innovative potentials.
To determine the impact of structural shifts on the industrial potential development we suggest to use data of an average number of regular workers, gross added value, capital investments and volume of the innovative products sold (table1).

Table 1

Structural transformations of the basic indicators of the industrial potential development by types of industrial activity, share, \%

\begin{tabular}{|c|c|c|c|c|c|}
\hline \multicolumn{2}{|c|}{$\begin{array}{c}\text { Types } \\
\text { of industrial activity }\end{array}$} & 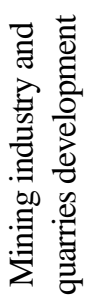 & 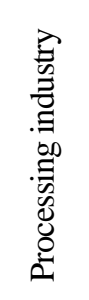 & 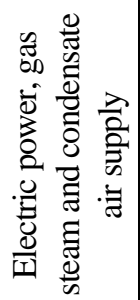 & 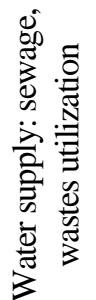 \\
\hline \multirow{2}{*}{$\begin{array}{l}\text { Gross added } \\
\text { value }\end{array}$} & 2010 & 25,98 & 58,44 & 12,41 & 3,17 \\
\hline & 2014 & 24,33 & 59,66 & 13,79 & 2,22 \\
\hline \multirow{2}{*}{$\begin{array}{c}\text { Capital } \\
\text { investments }\end{array}$} & 2010 & 27,73 & 53,91 & 17,06 & 1,30 \\
\hline & 2014 & 23,20 & 49,25 & 26,55 & 1,00 \\
\hline \multirow{2}{*}{$\begin{array}{l}\text { Average } \\
\text { number } \\
\text { of regular } \\
\text { workers }\end{array}$} & 2010 & 15,24 & 64,97 & 14,37 & 5,42 \\
\hline & 2014 & 13,45 & 65,78 & 15,15 & 5,62 \\
\hline \multirow{2}{*}{$\begin{array}{l}\text { Volume of } \\
\text { the innovative } \\
\text { products sold }\end{array}$} & 2010 & 0,75 & 99,25 & 0,00 & 0,00 \\
\hline & 2014 & 0,04 & 99,51 & 0,42 & 0,03 \\
\hline
\end{tabular}

From source: [7].

A tendency to increase of the share of capital investments, number of workers and gross added value is observed during the investigated period in the sphere of electric power, gas steam and condensate air supply (average annual rates of growth were 109,2 \%, 101,0\% and 102,1\% accordingly). At the same time, absolutely opposite dynamics is observed in mining industry and quarries development, where negative tendencies are found in all indicators of the industrial potential development. Such situation is mainly caused by unsatisfactory economic situation in the eastern regions of Ukraine that are the basic centers of the development of the mentioned industry.

The increase of share in the structure of employment, gross added value and volumes of realization of innovative products in processing industry (average annual rates of increase were $100,2 \%, 100,4 \%$ and $100,1 \%$ accordingly) took 


\section{Structural Development of Industrial Potential of Ukraine}

place regardless of capital investments share reduction, that indicates the perspectives of the industrial potential development of this industry. At the same time, reduction of capital investment share and gross added value in the field of a watersupply (average annual rates of recession were $94,89 \%$ and $93,12 \%$ accordingly) and increase of regular workers share proves ineffective development of the industrial potential and existence of structural deformations.

Research of interrelation between the structural changes of basic indicators of industrial potential development is conducted by coefficients of sensitiveness, that are calculated by the following formulas (1) in table 2:

$$
\begin{aligned}
& \Psi_{i}^{1}=\Delta V i / \Delta_{I i} ; Y_{i}^{2}=\Delta P_{i} / \Delta_{I i} ; \\
& \Psi_{i}^{3}=\Delta V i / \Delta_{P_{i}} ; \Psi_{i}^{4}=\Delta R i / \Delta_{I i},
\end{aligned}
$$

where $\Psi_{i}^{1}, \quad \Psi_{i}^{2}, \quad \Psi_{i}^{3}, \quad \Psi_{i}^{4}$ - are coefficients of sensitiveness of change rates of one indicator towards another in i-type of industrial activity during 20102014; $\Delta V_{i}, \Delta I_{i}, \Delta P_{i}, \Delta R_{i}$ - are average annual rates of share changes of gross added value, capital investments, average number of regular workers and volume of the innovative products sold of i-type of industrial activity during the analyzed period.

Table 2

\section{Coefficients of sensitiveness of structural transformations of the basic indicators of national industrial potential development by types of industrial activities}

\begin{tabular}{|c|c|c|c|c|}
\hline \multirow{2}{*}{$\begin{array}{c}\text { Type of } \\
\text { industrial } \\
\text { activity }\end{array}$} & \multicolumn{4}{|c|}{ Coefficients of sensitiveness } \\
\cline { 2 - 5 } & $\Psi_{i}^{1}$ & $\Psi_{i}^{2}$ & $\Psi_{i}^{3}$ & $\Psi_{i}^{4}$ \\
\hline $\begin{array}{c}\text { Mining } \\
\text { industry and } \\
\text { quarries } \\
\text { development }\end{array}$ & 1,01 & 1,01 & 1,01 & 0,58 \\
\hline $\begin{array}{c}\text { Processing } \\
\text { industry }\end{array}$ & 1,02 & 1,02 & 1,00 & 1,02 \\
\hline $\begin{array}{c}\text { Electric } \\
\text { power, gas } \\
\text { steam and } \\
\text { condensate } \\
\text { air supply }\end{array}$ & 0,93 & 0,93 & 0,92 & $\mathrm{x}$ \\
\hline $\begin{array}{c}\text { Water supply: } \\
\text { sewage, } \\
\text { wastes } \\
\text { utilization }\end{array}$ & 0,98 & 1,06 & 0,92 & $\mathrm{x}$ \\
\hline
\end{tabular}

From source: [7].
As we can see, the most effective structural changes of capital investments are in the processing industry, where the change of structure of capital investments on 1 r.p. (relative point) correspond to the change of 1,02 r.p. of structural transformations by volumes of gross added value, volume of the innovative products sold, average annual number of regular workers. The structural changes of capital investments in mining industry and quarries development provide changes in 1,01 r.p. in the structure of gross added value and average number of workers. At the same time, the change of structure of an average number of regular workers on 1 r.p. into structural changes by volumes of gross added value also correspond to the change of 1,01 r.p.

In most types of industries, that is in mining and quarries development, processing and water supply, structural changes of capital investments determine positive changes of other indicators. These results are logical and scientifically grounded. In fact, as early as in the $50^{\text {th }}$ of the last century Khansen E., a famous supporter of Keynesianism, grounded dependence of technical progress on capital investments [8].

We agree with E. V. Prushkivska's statement, that structural transformations are orientated on the criteria of economic development efficiency [9]. Taking it into account, impact of structural changes on the industrial potential development will be analyzed by the selection of efficiency indicators of the components, that is by the capital investments efficiency, fixed assets, labour and innovations on the basis of methodology suggested in the study [10, p. 136-140] (table 3).

Reduction of general efficiency of capital investments is the result of inefficiency of structural changes by the amount of capital investments in mining industry and quarries development $(-4,53$ r.p.), processing industry (-4,66 r.p.) and in the field of a water-supply ( $-0,30$ r.p.). The most positive results were received in electric power, gas steam and condensate air supply where the growth of the capital investments efficiency was $65,75 \%$. The most effective structural changes occurred in the processing industry and electric power, gas steam and condensate air supply by the indicator of an average number of workers where the growth of the capital investments efficiency was $9,50 \%$ and $5,40 \%$ correspondingly. The same tendencies are observed as for the development of social and 


\section{N. S. Stanasyuk}

labour component of the industrial potential. The reason of negative joint impact is negative tendencies of structural changes in mining industry and quarries development $(-78,14 \%$ and $-28,46 \%$ accordingly). Structural changes in the field of employment, capital investments and gross added value had the most positive influence on the efficiency of productive component growth of the industrial potential because positive results are received in most types of industries.
Nowadays, the development of industrial potential is not possible without implementing of innovations. Y. V. Vertakova and V. A. Plotnikov underline in their work the interrelation between innovative and industrial development and necessity of taking it into account with the aim of effective government regulation of the economy development of the country [11]. Impact of structural changes on innovations efficiency is mostly observed in the processing industry (table 4).

Table 3

Impact of structural shifts in the fields of employment, capital investments and gross added value on the efficiency of industrial potential development by types of industries

\begin{tabular}{|c|c|c|c|c|c|c|c|}
\hline \multirow{2}{*}{ Type of industrial activity } & \multicolumn{4}{|c|}{ Impact of structural shifts on efficiency } \\
\cline { 2 - 8 } & \multicolumn{2}{|c|}{$\begin{array}{c}\text { investment s } \\
\text { in the field of }\end{array}$} & \multicolumn{2}{|c|}{ fixed asset in the field of } & \multicolumn{2}{c|}{$\begin{array}{c}\text { labour potential } \\
\text { in the field of }\end{array}$} \\
\cline { 2 - 8 } & $\begin{array}{c}\text { employ- } \\
\text { ment }\end{array}$ & $\begin{array}{c}\text { invest- } \\
\text { ments }\end{array}$ & $\begin{array}{c}\text { employ- } \\
\text { ment } \mathrm{i}\end{array}$ & $\begin{array}{c}\text { investments } \\
\text { gross added } \\
\text { value }\end{array}$ & $\begin{array}{c}\text { employ- } \\
\text { ment }\end{array}$ & $\begin{array}{c}\text { gross added } \\
\text { value }\end{array}$ \\
\hline $\begin{array}{c}\text { Mining industry and quarries } \\
\text { development }\end{array}$ & $-14,07$ & $-35,59$ & 0,46 & 1,16 & 0,42 & $-78,14$ & $-28,46$ \\
\hline Processing industry & 9,50 & $-54,63$ & 0,10 & $-0,55$ & 0,14 & 23,07 & $-6,04$ \\
\hline $\begin{array}{c}\text { Electric power, gas steam and } \\
\text { condensate air supply }\end{array}$ & 5,40 & 65,75 & 0,03 & 0,32 & 0,05 & 27,62 & 4,02 \\
\hline $\begin{array}{c}\text { Water supply: sewage, wastes } \\
\text { utilization }\end{array}$ & $-5,30$ & 7,95 & 0,02 & $-0,03$ & $-0,10$ & 4,56 & 14,44 \\
\hline Compound growth rate & $-4,47$ & $-16,53$ & 0,60 & 0,90 & 0,52 & $-22,90$ & $-16,05$ \\
\hline
\end{tabular}

From source: [7].

\section{Impact of structural changes in the fields of employment and capital investments on the efficiency of innovative development of the processing industry}

\begin{tabular}{|c|c|c|}
\hline \multirow{2}{*}{ Type of activity } & \multicolumn{2}{c|}{$\begin{array}{c}\text { Impact on innovation efficiency of } \\
\text { structural changes in the field of }\end{array}$} \\
\cline { 2 - 3 } investments \\
\hline employment & $-61,79$ \\
\hline Production of food products, beverages and tobacco goods & $-12,87$ & 0,40 \\
\hline Textile production, production of clothing, skin, goods from skin \\
and other materials & 0,61 & $-5,36$ \\
\hline Production of goods from wood, paper production and printing activity & $-10,99$ & $-543,81$ \\
\hline Production of coke, products of oil processing & $-94,93$ & 47,51 \\
\hline Production of chemicals and chemical products & 2,51 & $-24,05$ \\
\hline Production of basic pharmaceutical products and pharmaceutical drugs & $-8,94$ & 51,78 \\
\hline Production of rubber and plastic goods; other non-metal mineral products & 5,47 & $-57,37$ \\
\hline Metallurgical production, production of metal complete goods, except \\
machines and equipment & 10,23 & 3,78 \\
\hline Production of computers, electronic and optical products & 8,81 & $-1,76$ \\
\hline Production of electric equipment & 1,37 & 7,44 \\
\hline Production of machines and equipment, which don't belong to other categories & 9,91 & $-6,02$ \\
\hline Production of vehicles, trailers and semitrailers and other transport vehicles & $-29,54$ & 2,84 \\
\hline Production of furniture, other products, repair and assembly & 20,53 & $-58,40$ \\
\hline of machines and equipment & $-97,83$ & $-586,40$ \\
\hline Compound growth rate & & 2 \\
\hline
\end{tabular}

From source: [6]. 


\section{Structural Development of Industrial Potential of Ukraine}

Obtaining of negative growth by the given indicator is connected, first of all, with the decrease of innovative activity level of industrial enterprises. The conducted analysis showed that structural changes were the most effective in the production of rubber and plastic goods; other non-metal mineral products (efficiency growth of the fixed assets was 5,47 \% and 51,78\% accordingly), chemicals and chemical products, furniture, machines and equipment.

\section{Conclusions and perspectives for further researches}

Analysis of structural changes impact on the development of industrial potential is done on the basis of setting up cause-and effect relations between primary indicators that characterize the development of the potential components and the criteria of the development efficiency taking into account the dynamics of their changes. Tendencies of the development of the main components of the industrial potential have been defined on the basis of the analysis results of structural changes of primary indicators. Interrelation between structural changes in the field of capital investments, employment, production and innovations is set with the help of the coefficients of sensitiveness. Conducted calculations showed mainly negative tendencies as to the structural development of the industrial potential. Regardless of positive results received on the industrial and economic component, efficiency of the industry fixed assets is extremely low. Obtained results prove the necessity to conduct effective government regulation of structural development of the industrial potential, taking into account distinguished causeand effect relations as its basis. Establishing of competitive structure of industrial potential under the conditions of economic transformation of the country will become a direction of further scientific researches as it will promote the accumulation of one's own financial resources, attraction of investments into the development of industry and introduction of innovations. Industrial potential must become the basis of establishing of innovative-directed economy in Ukraine.

\section{Reference}

1. Keyns Dzh. M. Obshchaya teoryya zanyatosty, protsentov y deneh / Dzh. M. Keyns // Antolohyya ékonomycheskoy klassyky. - M., Helyos ARV, 2002. $-458 s$.

2. Harrod R. Economic Essays / R. Harrod. - L., 1952. - $265 \mathrm{p}$.

3. Domar E. Essay in the Theory of Economics Growth / E. Domar. - N. Y. $-1957 .-8$ p.

4. Halchynskyy A. Lohika samorozvytku ekonomiky zavzhdy rozumna / A. Halchynskyy // FORBES vid 25 hrudnya $2015 r$.

5. Chayka Yu. Mekhanizmy strukturnoho rozvytku natsionalnoyi ekonomiky / Yu. Chayka // Visnyk KNTEU. - 2011. - No. 3. - S. 30-41.

6. Pasinovych I. I. Strukturnyy rozvytok ekonomiky ta suchasni vyklyky strukturnoyi transformatsiyi $v$ Ukrayini / I. I. Pasinovych // Sotsialno-ekonomichni problemy suchasnoho periodu Ukrayiny: zb. nauk. pr. - 2016. - No. 117 (1). - S. 82-87.

7. Vidkryta statystychna baza Derzhavnoyi sluzhby statystyky Ukrayiny. - Elektronnyy resurs. Rezhym dostupu: http://www.ukrstat.gov.ua.

8. Khansen É. Ékonomycheskyy tsykl y natsyonalnyy dokhod /É. Khansen. - M., 1959. - 602 s.

9. Prushkivska E. V. Evolyutsiya kontseptsiy strukturuvannya natsionalnoyi ekonomiky / E. V. Prushkivska // Problemy ekonomiky. - 2013. - No. 2. - S. 87-94.

10. Melnyk M. I. Formuvannya biznes-seredovyshcha Ukrayiny $v$ umovakh instytutsiynykh transformatsiy: monohrafiya / M. I. Melnyk. - Lviv: IRD NAN Ukrayiny, 2012. -568 s.

11. Vertakova Y. Innovative and industrial development: specifics of interrelation / Y. Vertakova, V. Plotnikov // Economic Annals-XXI. - 2016. No. 156 (1-2). - P. 37-40. 
